\title{
New material of Laophis crotaloides, an enigmatic giant snake from Greece, with an overview of the largest fossil European vipers
}

\author{
Georgios L. Georgalis ${ }^{1,2} \cdot$ Zbigniew Szyndlar $^{3} \cdot$ Benjamin P. Kear ${ }^{4,5}$. \\ Massimo Delfino ${ }^{2,6}$
}

\begin{abstract}
Laophis crotaloides was described by Richard Owen as a new and very large fossil viperid snake species from Greece. The type material is apparently lost and the taxon was mostly neglected for more than a century. We here describe a new partial viperid vertebra, collected from the same locality and of equivalent size to the type material. This vertebra indicates that at least one of the three morphological characters that could be used to diagnose $L$. crotaloides is probably an artifact of the lithographer who prepared the illustration supporting the original description. A revised diagnosis of $L$. crotaloides is provided on the basis of the new specimen. Despite the fragmentary nature of the new vertebra, it confirms the validity of $L$. crotaloides, although its exact relationships within Viperidae remain unknown. The new find supports the presence of a
\end{abstract}

Georgios L. Georgalis

dimetrodon82@gmail.com

1 Department of Geosciences, University of Fribourg, Chemin du Musée 6, 1700 Fribourg, Switzerland

2 Department of Earth Sciences, University of Torino, Via Valperga Caluso 35, 10125 Turin, Italy

3 Institute of Systematics and Evolution of Animals, Polish Academy of Sciences, Slawkowska 17, 31016 Krakow, Poland

4 Museum of Evolution, Uppsala University, Norbyvägen 16, 75236 Uppsala, Sweden

5 Palaeobiology Programme, Department of Earth Sciences, Uppsala University, Villavägen 16, 75236 Uppsala, Sweden

6 Institut Català de Paleontologia Miquel Crusafont, Universitat Autònoma de Barcelona, Edifici ICTA-ICP, Carrer de les Columnes s/n, Campus de la UAB, ES-08193 Cerdanyola del Vallès, Barcelona, Spain large viperid snake in the early Pliocene of northern Greece, adding further data to the diversity of giant vipers from Europe.

Keywords Serpentes · Viperids $\cdot$ Neogene $\cdot$ Greece . Gigantism

\section{Introduction}

In 1857, the eminent British palaeontologist Richard Owen described Laophis crotaloides, a new species of viperid snakes, on the basis of 13 large, fossilized vertebrae from Megalo Emvolon, near Thessaloniki, northern Greece. According to Owen, the vertebrae apparently belonged to a very large viperid with striking similarity to modern rattlesnakes (Crotalus). Ever since, Laophis has been regarded a mystery for ophidian palaeontology, with almost all subsequent authors neglecting it or considering it problematic, even if its proposed dimensions of more than three meters reached mythical standards (Kuhn 1939; Hoffstetter 1955; Rage 1984; Szyndlar 1991; Szyndlar and Rage 2002).

Here we report on a previously undescribed vertebra of a large snake from the same area of the type locality of $L$. crotaloides in northern Greece. Although the vertebra is fragmentary, it shares with the former taxon, overall large size and clear viperid features. This vertebra is here assigned to the species $L$. crotaloides and it currently represents the only available specimen for this taxon. Unfortunately, the fragmentary nature of the new vertebra precludes any precise conclusions about the taxonomic status of this taxon and the affinities of Laophis within the other members of the Viperidae cannot be clarified. Nevertheless, this new material confirms the validity of the 
taxon and further points that certain vertebral characters featured in the original description by Owen (1857) were in fact inaccurate. The occurrence and diversity of giant vipers in the European fossil record is discussed.

\section{Materials and methods}

The fossil material described in this study consists of an isolated vertebra that was collected in the early 1980s by Hans de Bruijn and Constantin Doukas in the locality of Megalo Emvolon, Greece. The vertebra is curated in the collections of the Institute of Earth Sciences Utrecht (The Netherlands) under the catalogue number KB3. Institutional Abbreviations are: KB, Karabournou collection of the Institute of Earth Sciences Utrecht (The Netherlands); MDHC, Massimo Delfino herpetological collection, Department of Earth Sciences of the University of Torino (Italy); NHM, The Natural History Museum, London (UK).

\section{Geological setting and palaeoecology}

\subsection{Geology of Megalo Emvolon}

Karabournou (also known as Karabournu, Karaburun or Falaise de Karaburun) is an old name for the modern Megalo Emvolon. Megalo Emvolon is situated in the northern part of the Gonia Formation, very near the city of Thessaloniki in the prefecture of Central Macedonia, northern Greece (Koufos et al. 1991). The Gonia Formation is highly fossiliferous and consists of both lenticular and massively bedded clays, sandstones, marls, and marly limestones (Syrides 1990). The locality of Megalo Emvolon was first discovered by Arambourg in the 1910s and is well known for its large mammals (Arambourg and Piveteau 1929; Koufos 2006). There is not a clear fossiliferous horizon in Megalo Emvolon, but several small fossil concentrations, which are dispersed across the deposits. It comprises three different fossiliferous levels: a lower one, Megalo Emvolon 1 (MEV), situated in the grey argillaceous sands near the bottom of the outcrop near the sea; Megalo Emvolon 2 (MEM), situated around twenty meters above MEV, above a bed with red sands and gravels; and Megalo Emvolon 3 (MEL), situated around ten meters above MEM, near the top of the section (Koufos et al. 1991). The characters of the sediments indicate a rapid deposition and the mammal fossils recovered from MEV, MEM and MEL do not suggest any age differences (Boev and Koufos 2000). Fossils found before the study of Koufos et al. (1991), cannot be accurately assigned to a precise level of Megalo Emvolon. This is also the case for the lost type material of L. crotaloides. The Megalo Emvolon section faunistically conforms to the early Pliocene (Zanclean-earliest Piacenzian) late Ruscinian European Land Mammal Zone MN 15, estimated at 4.23.2 Ma (Koufos et al. 1991; Koufos 2006).

Remarks About the type locality of L. crotaloides, Owen (1857:199) just mentioned that Captain Spratt collected these fossils from "Karabournou, on the eastern coast of the Gulf of Salonica" (=Thessaloniki). It is therefore impossible to know exactly from which of the several small fossil concentrations of Megalo Emvolon the snake vertebrae were collected. Captain Thomas Abel Brimage Spratt was heavily interested in fossils and had collected during his voyages with the British Navy across the Mediterranean, numerous specimens from several localities (Maempel 1986). He was also the author of several papers dealing with the geology of the localities he visited (Spratt 1842, 1847). Spratt is known to have visited the Thessaloniki area in March 1854, serving on the ship "Spitfire" (Maempel 1986) and he personally described the geology of the region three years later (Spratt 1857). In this paper, Spratt (1857:183) mentioned that he found the snake vertebrae, along with an indeterminate large mammal, "in the marls at about one mile N. E. of the Cape" (=Megalo Emvolon).

Given that the geology of Megalo Emvolon was not well established until the analysis of Koufos et al. (1991), several authors considered the age of Laophis as late Miocene (Zittel 1887-1890; Hoffstetter 1938, 1955; Kuhn 1939, 1963; Romer 1956; Młynarski et al. 1982), while Rage (1984) and Szyndlar (1991) regarded it as latest Miocene or earliest Pliocene.

\subsection{Palaeoecology of Megalo Emvolon}

The mammal fauna of Megalo Emvolon is speciose and relatively well studied. It includes the bovids Gazella borbonica, Koufotragus bailloudi and Parabos macedoniae, the suid Sus minor, the equid Hipparion longipes, various rodents and lagomorphs, the canid Nyctereutes donnezani, as also the cercopithecid Dolichopithecus ruscinensis (Arambourg and Piveteau 1929; Steffens et al. 1979; de Bruijn 1984; Koufos et al. 1991; Koufos and Koliadimou 1993; Koufos 1997), all indicative of a late Ruscinian (MN 15) age (Koufos 2006). The avifauna of Megalo Emvolon comprises only one bird fossil, the peafowl Pavo bravardi (Boev and Koufos 2000). Reptiles are represented by L. crotaloides (the only squamate recovered from the locality) and numerous small and giant tortoises (Bachmayer et al. 1980; Georgalis and Kear 2013). The mammal fauna indicates a semi-arid environment for Megalo Emvolon (Eronen and Rook 2004). 


\section{Systematic palaeontology}

Squamata OPPEL 1811. Serpentes LINNAEUS 1758. Viperidae OPPEL 1811.

\subsection{Genus Laophis OWEN 1857}

\section{Type species L. crotaloides OWEN 1857.}

Etymology Owen (1857) provided a short etymology only for his new genus name: Laophis derives from the Greek words Las $(\Lambda \tilde{\alpha} \varsigma)$, meaning stone in the ancient Doric dialect, and -ophis (öprs) denoting snake. Gender is masculine. Interestingly, another genus that shares an identical etymology, Lithophis [translated also as "stone snake" in Greek ( $\lambda i \theta$ os + ö $\varphi 1 \varsigma)]$, has a similarly obscure taxonomic status, as it is just represented by a single fragmentary precloacal vertebra from the Eocene of Wyoming, USA (Marsh 1871; Rage 1984).

Diagnosis As for L. crotaloides, the only known species.

\subsection{Laophis crotaloides OWEN 1857 (Figs. 1, 2a)}

Holotype 13 precloacal vertebrae (Fig. 1). No catalogue number formally designated (Owen 1857) and the original material is now lost (Rage 1984; Szyndlar 1991; Szyndlar and Rage 2002). Our attempt to relocate the type material of L. crotaloides was not successful as well: the type material is not listed in the catalogues of the Natural History Museum in London (NHM) and apparently it is not present in the collections (S. Chapman, pers. comm. to M. D.).
It is impossible to determine if the type material ever entered the collections of the NHM. After the collection of the fossils by Captain Spratt, they were immediately sent to E. Forbes and deposited in the Museum of Economical Geology (later renamed as the Museum of Practical Geology, also known as the Geological Museum), in Jermyn Street, London (Spratt 1857) and apparently it was still present 3 years later, when Owen (1857) studied and published it. It is known, however, that by the end of the nineteenth century, the display cases of the museum were so overcrowded that it became necessary to discard all material not closely connected to the work and purposes of the Geological Survey (NHM Archives, accessed November 2015). It therefore is plausible that the 13 isolated vertebrae of $L$. crotaloides were not considered impressive enough and were discarded. Moreover, the collections of the Museum of Practical Geology are now part of the collections of the Natural History Museum, London and are known to have moved from Jermyn Street to Exhibition Road, South Kensington in 1935. The L. crotaloides type material could therefore have been lost during this collection transfer.

New referred specimen $\mathrm{KB} 3$, an incomplete precloacal vertebra (Fig. 2a).

Etymology Species name etymology was not provided in the original description by Owen, but it apparently refers to the rattlesnake genus Crotalus (Crotalinae) and -oides (oєı $\delta \dot{\varepsilon} \zeta$ ) for like. Gender is masculine. As such, the name $L$. crotaloides could translate as the "rattlesnake-like stone snake". We note that the diacritic mark used in the original spelling "crotaloides" is removed here following ICZN (1999) Article 32.5.2.1.
Fig. 1 Type vertebra of Laophis crotaloides modified from the original publication by Owen (1857). Image not to scale (originally depicted by Owen 1857 in natural size). $A$ anterior view, $L$ lateral view
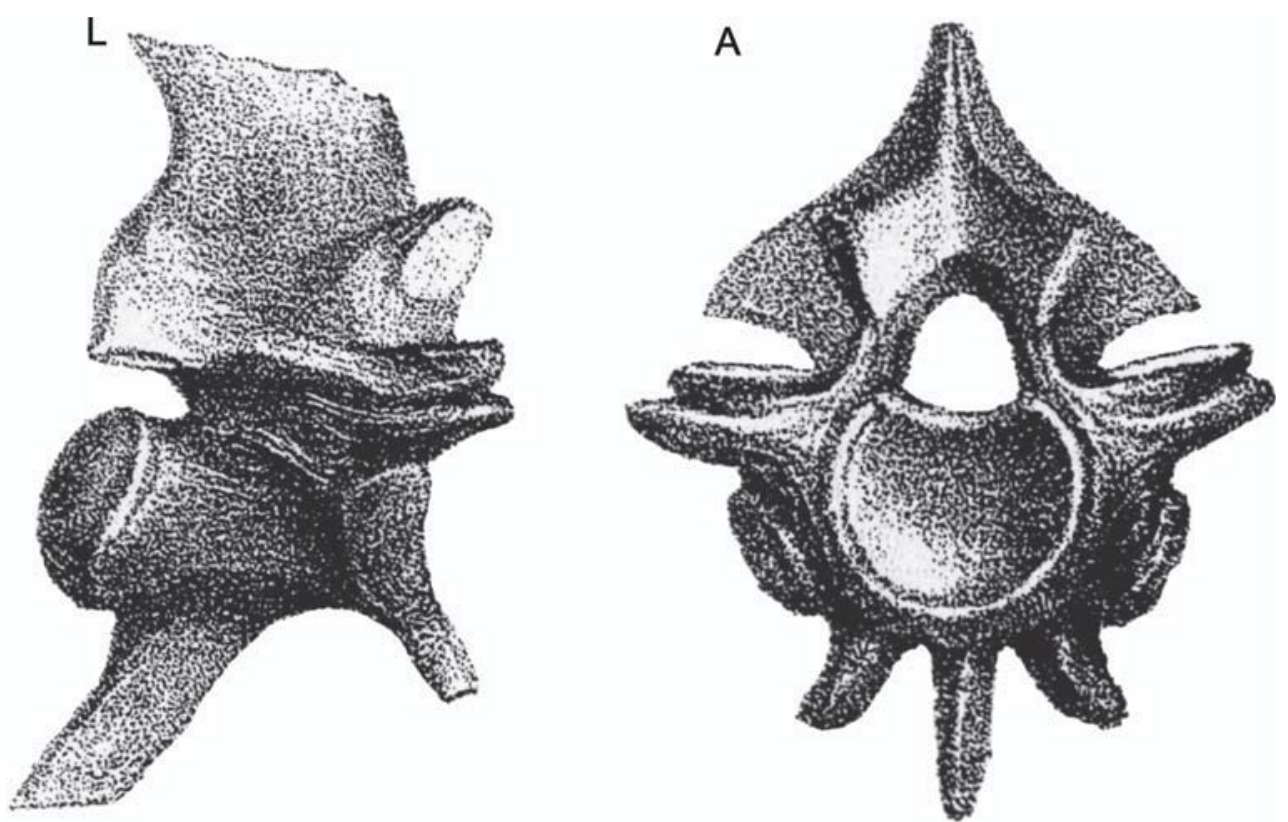

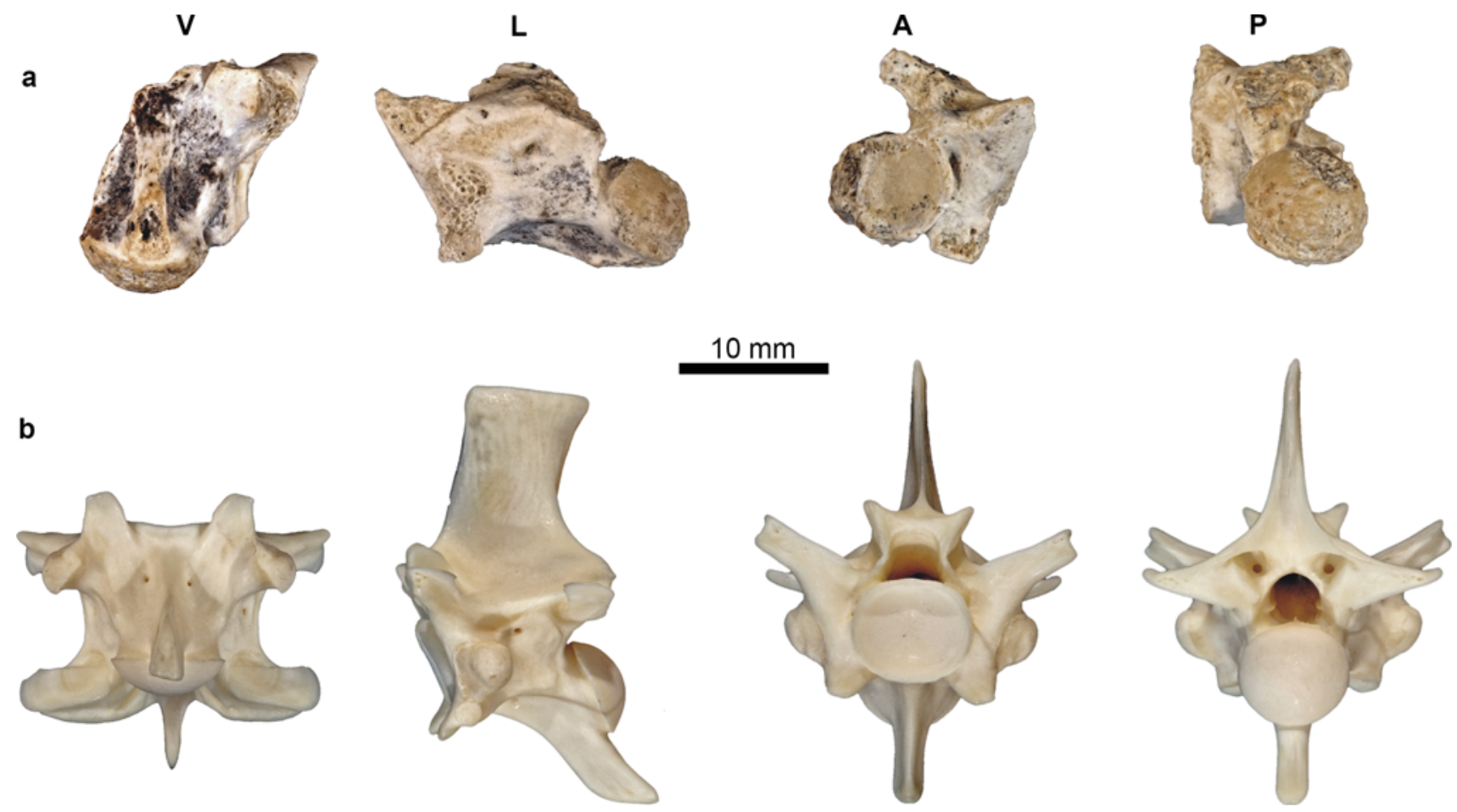

Fig. 2 a Precloacal vertebra KB3, referred to Laophis crotaloides. b Precloacal vertebra $(\mathrm{CL}=11.20 \mathrm{~mm})$ of the extant large viperid Bitis rhinoceros (specimen MDHC 100). Scale bar $10 \mathrm{~mm}$. $A$ anterior view, $L$ lateral view, $P$ posterior view, $V$ ventral view

Occurrence Megalo Emvolon (Central Macedonia, Greece), early Pliocene (late Ruscinian MN 15, equivalent to Zanclean to earliest Piacenzian). The taxon is known only from the type locality.

Differential diagnosis Taking into account the new specimen, $L$. crotaloides can be referred to the Viperidae on the basis of the proportionally wide cotyle and condyle (the latter of which is quite robust), the probable presence of hypapophysis, a relatively short centrum and, above all, the dorsally tilted prezygapophyseal facets (see characters in Szyndlar 1984, 1991). L. crotaloides can be differentiated from all other viperid snakes by the combination of the following characters: very large vertebral size (CL equal or larger than $15 \mathrm{~mm}$ ); centrum proportionally short and broad in ventral view; cotyle much wider than the neural canal; condyle stout and proportionally large, elliptical in shape and being slightly wider than tall; diapophyses probably more developed than the parapophyses; and well developed parapophyseal processes.

Remarks The size, shape, general morphology and overall proportions of the new vertebra KB3 match those of the type material of $L$. crotaloides (see below), but the length of the condylar neck and the thickness of the prezygapophyseal facets are not as developed as shown by Owen (1857).

\section{Description}

\subsection{The Laophis crotaloides type material described by Owen (1857)}

In the original description of L. crotaloides, Owen (1857: pl. 4) figured one of the 13 vertebrae representing the type material of his new taxon, but only in lateral and anterior views (Fig. 1). According to the original figures, the vertebra appears to be strongly elongated dorsoventrally in lateral view. The centrum is short, whereas the neural spine and the hypapophysis are very large. The zygosphenal roof seems to be concave. The condyle is rather robust. In anterior view, the zygosphenal roof is strongly convex (contra the situation figured in lateral view). The prezygapophyseal articular part is very thick. The cotyle is extremely large, almost twice the size of the neural canal, whereas it seems to be rather concave. As is discussed below, the inconsistency of the features of the zygosphene in anterior and lateral views, as also the long condylar neck, lead Rage (1984) and subsequently Szyndlar (1991) to consider these characters as a product of fantasy of the lithographer.

Laophis crotaloides was described by Owen as the largest viperid snake (Szyndlar 1991), indicating a size "between 10 and 12 feet in length" (Owen 1857:199). Thanks to the 
drawings provided by Owen in natural size, it is possible to estimate several vertebral measurements for the type vertebra of L. crotaloides, justifying Owen's claims: the length of the centrum measured in lateral view from the concavity between the dia- and parapophyses is about $15 \mathrm{~mm}$; the height of the vertebra from the tip of the neural spine to the tip of the hypapophysis is of at least about $30 \mathrm{~mm}$ (it is not clear if the neural spine was complete) if measured in lateral view and $28 \mathrm{~mm}$ if measured in anterior view; the distance between the lateral edges of the prezygapophyses is $32 \mathrm{~mm}$; the cotyle is about $9 \mathrm{~mm}$ wide.

\subsection{Specimen KB3}

The vertebra KB3 is fragmentary, having preserved only part of the left prezygapophysis, part of the left half of the neural arch, and slightly more than the left half of the centrum (Fig. 2a). The prezygapophysis preserves part of the articular facet (but it is not possible to evaluate its former shape and that of the prezygapophyseal processes) that appears to be anterolaterally oriented in dorsal view and is dorsally tilted in anterior view. The cotyle is only partially preserved but it was clearly very wide-much wider than the neural canal-and it is accompanied by a small paracotylar foramen placed close to the dorsolateral quadrant of the cotyle (only the left quadrant is preserved). The preserved portion of the cotyle rim, despite a little erosion, clearly indicates that the cotyle does not protrude significantly from the anterior profile of the vertebra. Diaand parapophysis are nearly entirely eroded but it seems that the former was more developed than the latter. The parapophyseal process was probably well developed as suggested by the remnants of its basis; the medial surface of the process was delimited by a small ridge. In ventral view, the centrum is proportionally short and broad. The centrum length (CL) can be estimated to be $15 \mathrm{~mm}$ (slightly higher-about $16.3 \mathrm{~mm}$-if measured in lateral view, from the concavity between the dia- and the parapophysis to the posterior tip of the condyle). The hypapophysis is not preserved with the exception of its anterior, keel-like prolongation. The posterior edge of the hypapophysial root reached the condyle. On each side of the keel, at mid centrum length, there is a tiny subcentral foramen laying in a deep subcentral groove laterally delimited by an evident subcentral ridge. A small lateral foramen is placed at the bottom of a funnel depression. Anterodorsally to this foramen, between the interzygapophyseal ridge and the eroded diapophysis, there is another depression with an elongated shape. The condyle is stout and proportionally large; it is elliptical in shape, being slightly wider (about $7.9 \mathrm{~mm}$ ) than tall (about $6.4 \mathrm{~mm}$ ). The ventral edge of the condyle is placed slightly posterior than the dorsal edge. The development of the condylar neck can be evaluated thanks to the landmark represented by the base of the posterior edge of the neural arch: even if it is quite apparent due to the absence of the posterior region of the neural arch, the space between the base of the latter and the anterior edge of the condyle is of about $1 \mathrm{~mm}$ and therefore, considering the length of the vertebra, the condylar neck is not significantly different from that of extant snakes, as was (probably erroneously) shown in the original description.

\section{Discussion}

\subsection{The mystery of Laophis crotaloides: taxonomic history, affinities and status}

The taxonomic status of $L$. crotaloides has been a mystery for ophidian palaeontology since its original description by Owen in 1857 . The fact that the type and previously only known material is considered lost, further hindered and complicated the knowledge of its affinities. As such, Laophis was mostly omitted in most subsequent publications regarding fossil snakes, with only few exceptions that treated it as a problematic taxon (Kuhn 1939, 1963; Rage 1984; Szyndlar 1991; Szyndlar and Rage 1999, 2002).

As mentioned above, Owen (1857) described and named the new species L. crotaloides on the basis of 13 isolated vertebrae that he compared with those of a number of extant species. He concluded that $L$. crotaloides bore close resemblance to modern vipers; however, the material was sufficiently distinct at the specific level. He further speculated affinities with rattlesnakes (Crotalinae), but he acknowledged that the limited available material could not allow him determine whether the 13 fossil vertebrae originated from the anterior or mid-trunk regions of the snake body and as such, no certain taxonomic conclusions could be made. Owen (1857) strongly emphasized the absolute size of his new taxon, pointing vertebral size similar with large extant pythonids.

There are not many discussions or mentions of L. crotaloides in the literature despite the more than 150 years since its original description. Römer (1870) noted that the vertebrae of $L$. crotaloides shared several characteristics with extant Crotalus. Rochebrune (1880) cited L. crotaloides in his list of fossil snakes, without any further comment. While, the idea of rattlesnake affinities of $L$. crotaloides was not concluded with certainty by Owen, Zittel (1887-1890) listed this taxon in Crotalidae, mentioning also Owen's (1857) size estimate of more than three meters for this taxon. Similar taxonomic affinities were later followed by Hoffstetter (1938), whereas 1 year later, Kuhn (1939) allocated L. crotaloides to Crotalidae (=Viperidae sensu lato, under the modern sense), the same 
family to which he assigned also the extant genus Vipera Laurenti, 1768. However, he did not provide any justification for the assignment of $L$. crotaloides to this group (Kuhn 1939). Later, Hoffstetter (1955) stated that L. crotaloides displayed indeed the characteristics of the Viperidae and was considered a crotaline snake; however, according to the same author, an alternative allocation of the Greek taxon to viperines, based solely on vertebrae, could not be excluded (Hoffstetter 1955). Romer (1956) made a brief mention on Laophis in his list of the genera of Crotalinae. Few years later, in his second edition of his snake volume of the "Fossilium Catalogus", Kuhn (1963) classified all known fossil viperids into two subfamilies, Viperinae and Crotalinae. Apparently influenced by Hoffstetter (1955), he continued to classify Laophis (as "? Laophis Owen, 1857") among the Crotalinae (Kuhn 1963:34), again with no further comments or justification explaining his decision. Młynarski et al. (1982) mentioned L. crotaloides in their description of the Miocene lower vertebrates from Opole, Poland. They referred to its age as Miocene and noted that $L$. crotaloides was the only European fossil snake attributed to Crotalinae known to date, even if it could not be shown with certainty that the taxon was a pit viper. In his complete treatise of fossil snakes, Rage (1984) considered that the characters used by Owen (1857) to establish L. crotaloides were widespread among viperids and that differentiation between viperines and crotalines simply on the basis of vertebral morphology was not possible. He additionally, considered the figures of Owen as inaccurate and further concluded that this taxon is a nomen dubium (Rage 1984). Three years later, Zerova et al. (1987) briefly hinted at L. crotaloides and briefly discussed the fact that this taxon could belong to crotalines. Later on, Szyndlar (1991) considered that taxonomic allocations of L crotaloides to crotalines were most probably suggested because of erroneous interpretations surrounding its specific epithet. The same author highlighted the large centrum length of the vertebra, further postulated affinities of this taxon with the African genus Bitis, based on overall vertebral morphology, and considered the validity of $L$. crotaloides as an open question. In his description of the enigmatic viperid "Coluber" kargii, Szyndlar (1992) mentioned L. crotaloides, briefly stating that its taxonomic distinctiveness from other viperids cannot be demonstrated. Other short references to L. crotaloides were made by Rage in Golay et al. (1993) and by Szyndlar (1995) a few years later. Ivanov (1999) mentioned L. crotaloides, referring to its age as "lowermost Pliocene", noting also that this taxon was considered by Rage (1984) as a nomen dubium. As his main aim was to describe a fossil pit viper from Ukraine, he cited Szyndlar (1991:245) in assuming that "Laophis might have been a Bitis-like snake rather than a pit viper", therefore leaving his Ukrainian fossil as the only European pit viper. Subsequently, Szyndlar and Rage (1999) mentioned $L$. crotaloides, noted that its systematic status is unclear, although its assignment to Viperidae is unquestionable. They continued considering this taxon as a nomen dubium. The same authors, three years later, mentioned again $L$. crotaloides in their complete review of the fossil record of viperines (Szyndlar and Rage 2002), noting that its taxonomic status is uncertain. The last published mention of $L$. crotaloides was made by Wallach et al. (2014) who followed Rage (1984) in considering this taxon a nomen dubium.

Systematic assignment of $L$. crotaloides is hindered by uncertainties surrounding its vertebral anatomy. According to Szyndlar (1991), besides its absolute size, L. crotaloides as described and figured by Owen is characterized by two features that distinguish it from other large viperids: very thin parapophyseal processes and the long condylar neck. The referral of KB3 to the same taxon suggests that the condylar neck was erroneously illustrated in Owen's original figures and an elongated condylar neck is not a character of $L$. crotaloides; the shape and size of the parapophyseal processes of KB3 cannot be evaluated because of preservation reasons. Even if KB3 cannot definitively address this question, it indicates that at least one of the potential diagnostic characters of this taxon was probably related to the inaccuracy of the figure accompanying the description. The fact that the drawing provided by Owen (1857) is not accurate is testified by the zygosphenal roof, which, as already reported by Rage (1984) and Szyndlar (1991), is strongly convex in anterior view, but not in lateral view. The extreme thickness of the prezygapophyseal articular part (according to Szyndlar 1991) shown by the figures published by Owen (1857) probably does not reflect the original morphology of the specimen, as suggested by the morphology of KB3.

The taxonomic status of $L$. crotaloides cannot be evaluated with certainty on the basis of the new material, and it is not possible to allocate this taxon to either crotalines or viperines. On the basis of biogeography, however, it seems more plausible that $L$. crotaloides is a viperine, as crotalines are totally absent from the European fossil record, with the exception of a single occurrence in the Miocene of Ukraine (Ivanov 1999). Taxonomic assignment within viperines (true vipers) cannot also be established with certainty. Whether or not L. crotaloides had affinities with the "Oriental vipers complex" or Daboia (where the largest European species belong; see below) cannot be verified. The absolute large size of the $L$. crotaloides vertebra could indicate strong affinities with the coeval and similarly sized viperids from Mallorca and Layna, Spain (Szyndlar 1988; Bailon et al. 2010; Torres et al. 2014). The large geographic distance between Greece and Spain should 
Table 1 Published occurrences of Greek fossil Viperidae

\begin{tabular}{|c|c|c|c|}
\hline Taxon & Locality & Age & References \\
\hline $\begin{array}{l}\text { Viperidae indet. ('oriental } \\
\text { vipers complex') }\end{array}$ & Maramena (Serres) & Latest Miocene (MN 13) & Szyndlar (1995) \\
\hline Laophis crotaloides & Megalo Emvolon (Thessaloniki) & Early Pliocene (MN 15) & Owen (1857); this paper \\
\hline $\begin{array}{l}\text { Viperidae indet. ('oriental } \\
\text { vipers complex') }\end{array}$ & Tourkobounia 1 (Attica) & Late Pliocene (MN 16) & Szyndlar (1991) \\
\hline Vipera cf. berus & Laghada B (Kos Island) & Early Pleistocene & Szyndlar (1991) \\
\hline Vipera cf. berus & Megalopolis (Peloponnese) & Middle Pleistocene & van Vugt (2000) \\
\hline $\begin{array}{l}\text { Viperidae indet. ('oriental } \\
\text { vipers complex') }\end{array}$ & Latomi (Chios Island) & Middle Pleistocene & $\begin{array}{l}\text { Schneider (1975) and } \\
\text { Szyndlar (1991) }\end{array}$ \\
\hline Vipera $\mathrm{cf}$. ammodytes & Tourkobounia 2 (Attica) & Middle Pleistocene & Szyndlar (1991) \\
\hline Vipera cf. berus & Tourkobounia 2 (Attica) & Middle Pleistocene & Szyndlar (1991) \\
\hline
\end{tabular}

probably prompt us to be cautious when dealing with such taxonomic assignments, but common faunal elements between Greek and Spanish Pliocene localities could favor this hypothesis. Both Megalo Emvolon and Layna localities share the same Hipparion species (Koufos et al. 1991) and as such, affinities of $L$. crotaloides with the large Spanish viperid Daboia maxima should not be ruled out. Moreover, the proximity of the Greek localities to western Asia and northern Africa, leaves the possibility that $L$. crotaloides was an immigrant from the East. Large fossil viperids from outside Europe are not sufficiently known, except for certain North American forms (Holman 2000). Judging from palaeobiogeography, affinities of $L$. crotaloides with large African Bitis spp. cannot be excluded. Vipers of the latter genus are also known to attain large size, exceeding $170 \mathrm{~cm}$ in total length (Spawls et al. 2002; Mallow et al. 2003). In fact, the vertebral morphology of Bitis spp. bears the closest resemblance with L crotaloides among all true vipers, as was already noted by Szyndlar (1991). Indeed, mid-trunk vertebrae of both genera "are strongly elongate dorso-ventrally in lateral view, owing to exceptionally long hypapophyses and neural spines together with relatively short centra" (Szyndlar 1991:244). Vertebrae of both Laophis (at least as it is shown in the original illustration of Owen) and Bitis are more than twice as high (distance between the hypapophyseal tip and neural spine top) as long (centrum length) (Szyndlar 1991) (Fig. 2). Bitis, however, has never been recorded from Europe with certainty-two purported records from the Miocene of Hungary (Kormos 1911) and Spain (Piveteau 1927) have since been shown to represent a non-Bitis viperid (Szyndlar 1984, 1991) and a colubrid (Szyndlar and Rage 2002) respectively. The African fossil record of squamates, that could potentially include large sized Bitis or Bitis-like forms, is not adequately sampled (Delfino et al. 2004; Rage and Bailon 2011) and this is unfortunately also the case for the Asian fossil viperids (Szyndlar and Rage
2002). With all the above taken into account, we cannot make any certain conclusions regarding the exact taxonomic affinities of $L$. crotaloides within the Viperidae. However, the taxon should no longer be considered a nomen dubium, as the new vertebra bears a unique combination of characters, above all the very large absolute size (CL more than $15 \mathrm{~mm}$ ), which can diagnose L. crotaloides as a distinct valid species.

\subsection{Fossil viperid snakes from Greece}

Viperids are conspicuous elements of the extant Greek herpetofauna, comprising several species, one of which is endemic (Valakos et al. 2008). Species that currently inhabit Greece include Vipera ammodytes LINNAEUS 1758, widespread throughout the Cyclades and Eastern Aegean Islands, Vipera berus LINNAEUS 1758, distributed in Macedonia and Thrace, Vipera ursinii BONAPARTE 1835, from central and northern Greece, Montivipera xanthina (GRAY 1849) in Thrace and Eastern Aegean Islands, and Macrovipera schweizeri (WERNER 1935), endemic to Milos Archipelago and Siphnos Island (Valakos et al. 2008).

The past distribution of viperids currently living in Greece is unclear due to the limited available fossil material and the scarcity of the remains, mostly lacking diagnostic features. Nevertheless, fossil viperids have been sporadically recovered from Greek localities (Table 1). Miocene vipers are almost absent from Greek localities, but this should be of no surprise, as reptiles in general are rather rarely documented from that period in Greece (Römer 1870; Richter 1995; Delfino et al. 2008; Georgalis et al. 2013; Georgalis et al. 2016). An indeterminate viperid from Maramena, Central Macedonia, represents an exception, as it is the only Miocene viper from Greece. The Maramena viperid has been assigned to the "Oriental vipers complex" and is believed to have reached a 
relatively large size (Szyndlar 1995). Apart from L. crotaloides and the material from Maramena, the only other Neogene viperid from Greece is recorded from the late Pliocene of Tourkobounia 1 in Attica (Fig. 4b). This has been referred to the "Oriental vipers complex" and represents a rather large taxon, having an estimated centrum length of $10.1 \mathrm{~mm}$ (Szyndlar 1991). It is worth noting that Szyndlar (1991:249) dubbed this specimen as "the largest viper known from East European sites." All other fossil occurrences of vipers from Greece represent Pleistocene records that could represent the extant species or indeterminate viperids. Most notable among them is a very large viperid from the Middle Pleistocene of Latomi, Chios Island, which bears strong vertebral resemblance (CL more than $6 \mathrm{~mm}$ ) with large-sized Macrovipera lebetina (Schneider 1975; Nilson and Andrén 1986; Szyndlar 1991), a

Table 2 Geographic and stratigraphic distribution of the largest European fossil viperids, along with their respective maximum vertebral CL

\begin{tabular}{|c|c|c|c|c|}
\hline Taxon & Locality & Age & $\begin{array}{l}\text { Maximum centrum } \\
\text { length }(\mathrm{CL})(\mathrm{mm})\end{array}$ & References \\
\hline $\begin{array}{l}\text { Laophis crotaloides (KB } 3 \\
\text { specimen) }\end{array}$ & $\begin{array}{l}\text { Megalo Emvolon, } \\
\text { Greece }\end{array}$ & Early Pliocene (MN 15) & 16.30 & This study \\
\hline $\begin{array}{l}\text { Laophis crotaloides (lost } \\
\text { holotype) }\end{array}$ & $\begin{array}{l}\text { Megalo Emvolon, } \\
\text { Greece }\end{array}$ & Early Pliocene (MN 15) & 15 & $\begin{array}{l}\text { Owen (1857) and Szyndlar } \\
\text { (1991) }\end{array}$ \\
\hline $\begin{array}{l}\text { Viperidae indet. ('oriental vipers } \\
\text { complex') }\end{array}$ & $\begin{array}{l}\text { Na Burguesa-1 } \\
\text { (Mallorca), Spain }\end{array}$ & $\begin{array}{l}\text { Pliocene (MN } \\
\text { 15/MN 16) }\end{array}$ & $15^{\mathrm{a}}$ & Torres et al. (2014) \\
\hline $\begin{array}{l}\text { Viperidae indet. ('oriental vipers } \\
\text { complex') }\end{array}$ & $\begin{array}{l}\text { Calo den Rafelino } \\
\text { (Mallorca), Spain }\end{array}$ & $\begin{array}{l}\text { Pliocene (MN } \\
\text { 15/MN 16) }\end{array}$ & 12.70 & Bailon et al. (2010) \\
\hline $\begin{array}{l}\text { Daboia maxima ('Daboia } \\
\text { complex') }\end{array}$ & Layna, Spain & Early Pliocene (MN 15) & 11.80 & $\begin{array}{l}\text { Szyndlar (1988) and Szyndlar } \\
\text { and Rage (1999) }\end{array}$ \\
\hline $\begin{array}{l}\text { Viperidae indet. ('oriental vipers } \\
\text { complex') }\end{array}$ & Langenau, Germany & Early Miocene (MN 4) & 10.50 & Szyndlar and Rage (1999) \\
\hline $\begin{array}{l}\text { Viperidae indet. ('Daboia } \\
\text { complex') }\end{array}$ & $\begin{array}{l}\text { Vieux-Collonges, } \\
\text { France }\end{array}$ & $\begin{array}{l}\text { Early to middle } \\
\text { Miocene (MN } \\
\text { 4/MN 5) }\end{array}$ & 10.20 & Szyndlar and Rage (1999) \\
\hline $\begin{array}{l}\text { Viperidae indet. ('oriental vipers } \\
\text { complex') }\end{array}$ & $\begin{array}{l}\text { Tourkobounia 1, } \\
\text { Greece }\end{array}$ & Late Pliocene (MN 16) & 10.10 & Szyndlar (1991) \\
\hline $\begin{array}{l}\text { Macrovipera lebetina ('oriental } \\
\text { vipers complex') }\end{array}$ & Aetokremnos, Cyprus & Holocene & 10.07 & Bailon (1999) \\
\hline $\begin{array}{l}\text { Viperidae indet. ('Oriental vipers } \\
\text { complex') }\end{array}$ & $\begin{array}{l}\text { Vallée de la } \\
\text { Canterrane, France }\end{array}$ & $\begin{array}{l}\text { Pliocene } \\
\quad \text { (undetermined) }\end{array}$ & 9.67 & Bailon (1991) \\
\hline $\begin{array}{l}\text { Macrovipera sarmatica ('oriental } \\
\text { vipers complex') }\end{array}$ & Calfa, Moldova & Late Miocene (MN 9) & 9.40 & $\begin{array}{l}\text { Zerova et al. (1987) and } \\
\text { Szyndlar (1991) }\end{array}$ \\
\hline $\begin{array}{l}\text { Macrovipera kuchurganica } \\
\text { ('oriental vipers complex') }\end{array}$ & Kuchurgan, Ukraine & Early Pliocene (MN 14) & 9.10 & $\begin{array}{l}\text { Zerova et al. (1987) and } \\
\text { Szyndlar (1991) }\end{array}$ \\
\hline $\begin{array}{l}\text { Viperidae indet. ('oriental vipers } \\
\text { complex') }\end{array}$ & La Grive, France & $\begin{array}{l}\text { Middle Miocene (MN } \\
\text { 7/MN 8) }\end{array}$ & 8.70 & Szyndlar and Rage (1999) \\
\hline $\begin{array}{l}\text { Viperidae indet. ('oriental vipers } \\
\text { complex') }\end{array}$ & Rustavi, Georgia & Late Miocene (MN 10) & 8.60 & $\begin{array}{l}\text { Zerova et al. (1987) and } \\
\text { Szyndlar and Rage (2002) }\end{array}$ \\
\hline $\begin{array}{l}\text { Viperidae indet. ('oriental vipers } \\
\text { complex') }\end{array}$ & Artenay, France & Early Miocene (MN 4) & 8.60 & Szyndlar and Rage (1999) \\
\hline $\begin{array}{l}\text { Viperidae indet. ('oriental vipers } \\
\text { complex') }\end{array}$ & Iles Medas, Spain & Late Pliocene (MN 16) & 8.40 & Bailon (1991) \\
\hline $\begin{array}{l}\text { Viperidae indet. ('oriental vipers } \\
\text { complex') }\end{array}$ & Steinheim, Germany & $\begin{array}{l}\text { Middle Miocene (MN } \\
\text { 7/MN 8) }\end{array}$ & 8.30 & Szyndlar and Rage (1999) \\
\hline $\begin{array}{l}\text { Viperidae indet. ('oriental vipers } \\
\text { complex') }\end{array}$ & Maramena, Greece & Late Miocene (MN 13) & 8.10 & Szyndlar (1995) \\
\hline $\begin{array}{l}\text { Viperidae indet. ('oriental vipers } \\
\text { complex') }\end{array}$ & $\begin{array}{l}\text { Sandelzhausen, } \\
\text { Germany }\end{array}$ & $\begin{array}{l}\text { Middle Miocene } \\
\text { (MN 6) }\end{array}$ & 8.10 & Szyndlar and Rage (1999) \\
\hline
\end{tabular}

${ }^{a}$ It is not possible to know the CL of the Na Burguesa-1 vertebra because it is incomplete. Torres et al. (2014) provide a measurement of the distance from the anterior tip to the prezygapophysis to the posterior tip of the postzygapophysis: $15.1 \mathrm{~mm}$. This distance is smaller than the CL in viperid snakes, a fact that was also reevaluated by additional measurements in the vertebrae of Agkistrodon piscivorus (MDHC 103), Bitis rhinoceros (MDHC 100) and Macrovipera lebetina (MDHC 317) 


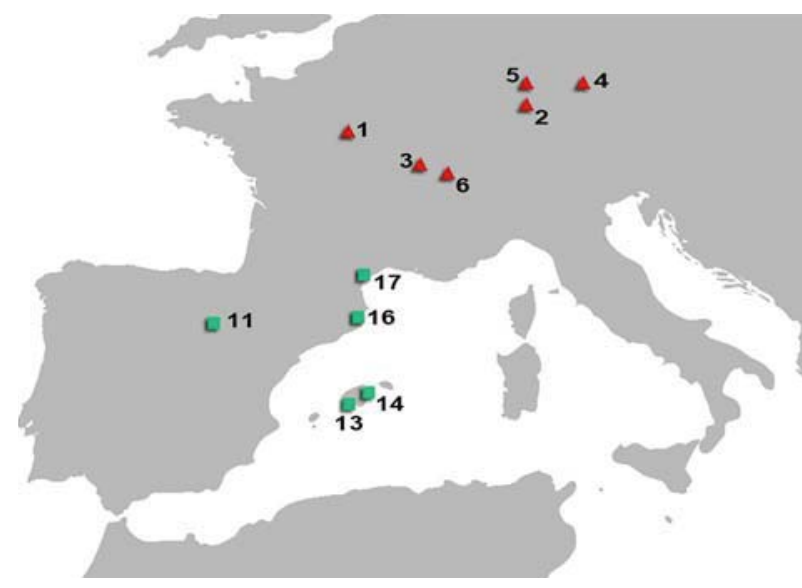

Fig. 3 Map of Europe, indicating the fossil localities bearing large viperids ( $\mathrm{CL} \geq 8 \mathrm{~mm}$ ). Triangles represent Miocene, squares represent Pliocene and circles represent Pleistocene and Holocene localities. 1 Artenay (France), 2 Langenau (Germany), 3 Vieux-Collonges (France), 4 Sandelzhausen (Germany), 5 Steinheim (Germany), 6 La Grive (France), 7 Calfa (Moldova), 8 Rustavi (Georgia), 9

species that does not occur in the extant herpetofauna of the country.

\subsection{Gigantism among European Viperidae}

With a maximum estimated centrum length (CL) of $16.3 \mathrm{~mm}$, the new vertebra of $L$. crotaloides ranks as the largest one among European viperids (Table 2). It is beyond the scope of this paper to provide a size estimation for $L$. crotaloides based on vertebral dimensions. Nevertheless, large to very large body sizes have been documented several times among the fossil record of European vipers (Rage 1984; Szyndlar 1991). Viperid snakes first appeared in Europe during the early Miocene (MN 1) (Kinkelin 1892; Rage 1984; Szyndlar 1987b; Szyndlar and Rage 2002; Čerňanský et al. 2015), becoming quickly widespread throughout the continent (Szyndlar 1991) and achieving large sizes already by the MN 4 (Szyndlar and Rage 1999) (Fig. 3). The appearance of large-sized viperids in Europe slightly coincides with the Miocene Climatic Optimum (Böhme 2003). Regarding the taxonomy of the European viperids to the genus level, several different approaches have appeared in the literature, most of which are based strictly on molecular data (Nilson and Andrén 1986; Herrmann et al. 1992; Lenk et al. 2001), as few or no osteological characters are known that could support such division (Bailon et al. 2010). We follow here the subdivision of viperines according to Szyndlar and Rage (1999) who focused on the morphology of the trunk vertebrae of viperines, a study that could directly apply to fossil specimens. These groupings are the "Vipera berus complex", "Vipera aspis complex", "Oriental
Maramena (Greece), 10 Kuchurgan (Ukraine), 11 Layna (Spain), 12 Megalo Emvolon (Greece), 13 Calo den Rafelino (Spain), $14 \mathrm{Na}$ Burguesa-1 (Spain), 15 Tourkobounia 1 (Greece), 16 Iles Medas (Spain), 17 Vallée de la Canterrane (France), 18 Aetokremnos (Cyprus)

vipers complex" and Daboia. The former two comprise relatively small taxa, whereas the latter two comprise the largest ones (Szyndlar and Rage 1999; Bailon et al. 2010).

Daboia, an extant Asian genus, is represented in Europe only by $D$. maxima (originally placed in Vipera), which was described by Szyndlar (1988) as a new large viperid species from the Pliocene (MN 15) of Layna, Spain (Fig. 4a). This species was initially assigned to the "Oriental vipers complex", as this group is known to possess much larger and relatively shorter vertebral centra, comparing to other European vipers (Szyndlar 1987a, 1988, 1991). However, it is now believed that Daboia is excluded from this group, as this genus can be differentiated from the "Oriental vipers complex" on the basis of the trunk vertebrae showing a greater development of the neural spine, which is higher than long (Szyndlar and Rage 1999; Bailon et al. 2010). With a vertebra centrum length and centrum width of 11.80 and $10.32 \mathrm{~mm}$ respectively, this Spanish taxon was supposed to be the largest viperine species (Szyndlar and Rage 2002). However, these vertebral dimensions are still smaller than the original type material of $L$. crotaloides and the new referred specimen. Another possible occurrence of Daboia in Europe could be an indeterminate large viperid from the early to middle Miocene of Vieux-Collonges, France (Szyndlar and Rage 1999) (Fig. 4e).

The so called "Oriental vipers complex" (genera Macrovipera and Montivipera) comprises some of the largest viperine species (Szyndlar 1991). This group has currently a very small distribution in Europe, existing only in the easternmost mainland Greece, the Cyclades islands, Cyprus, and European Turkey, but had achieved a much wider distribution during the Neogene (Szyndlar 1991). 

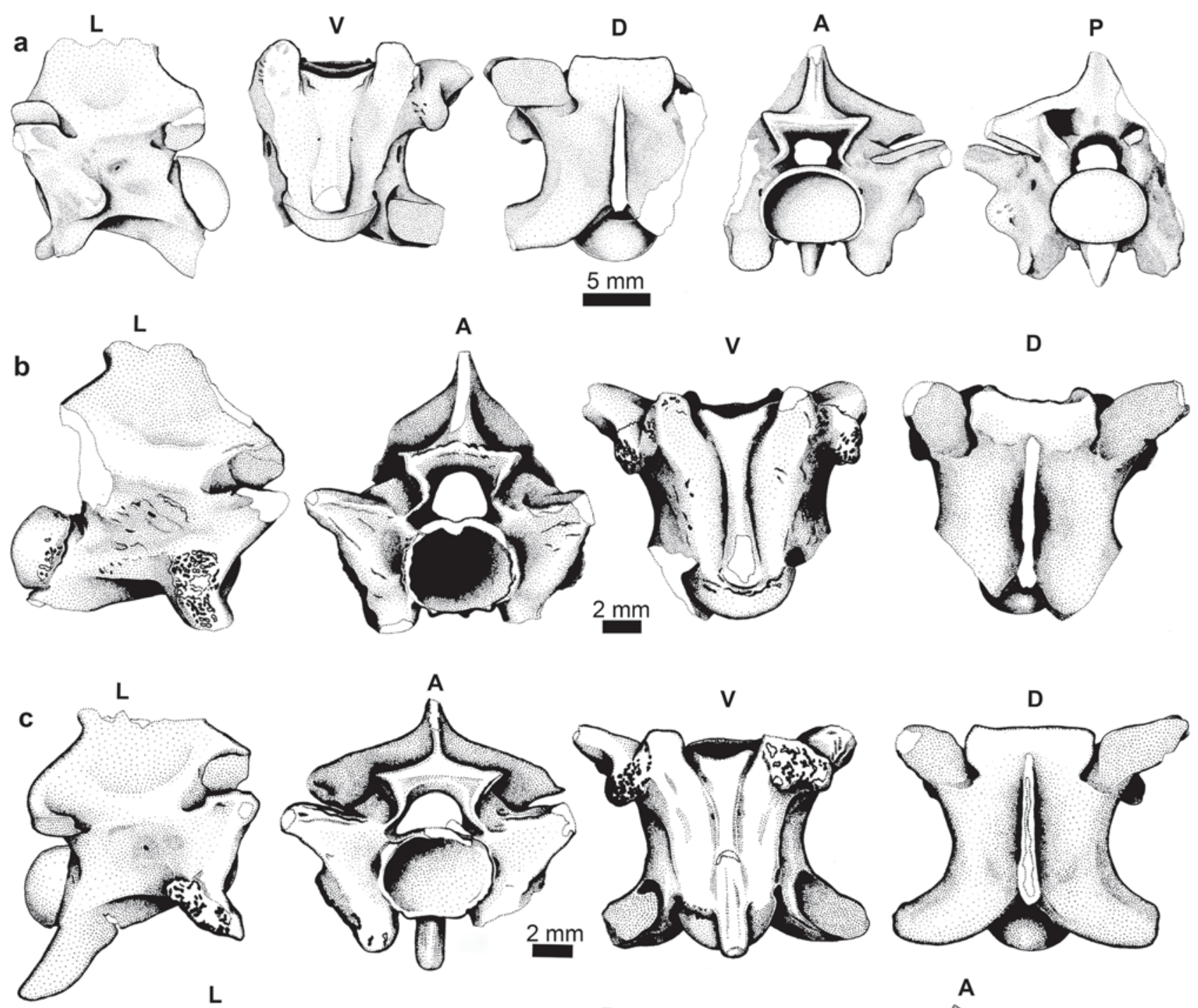

d
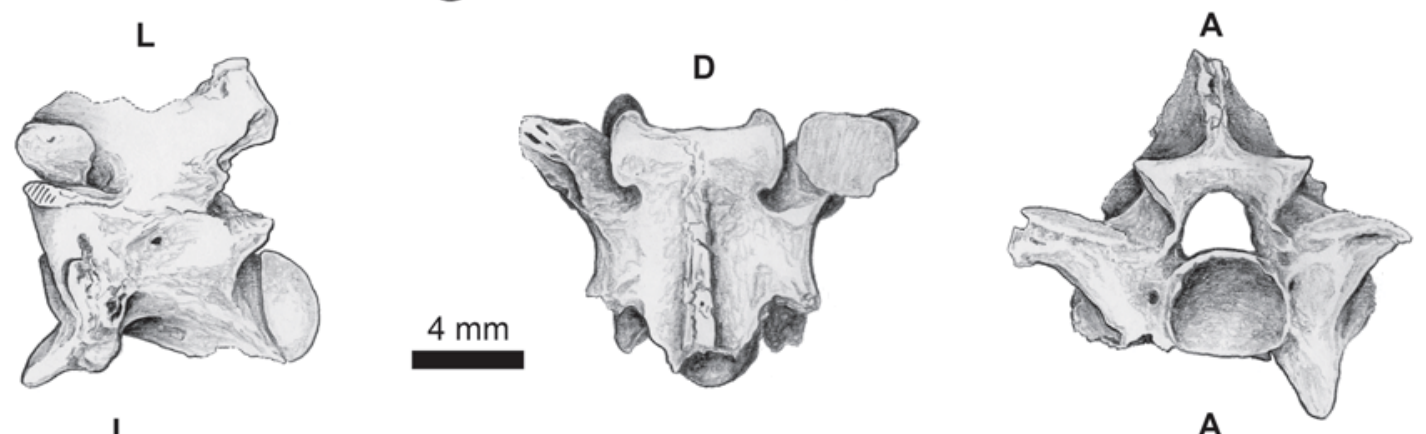

e
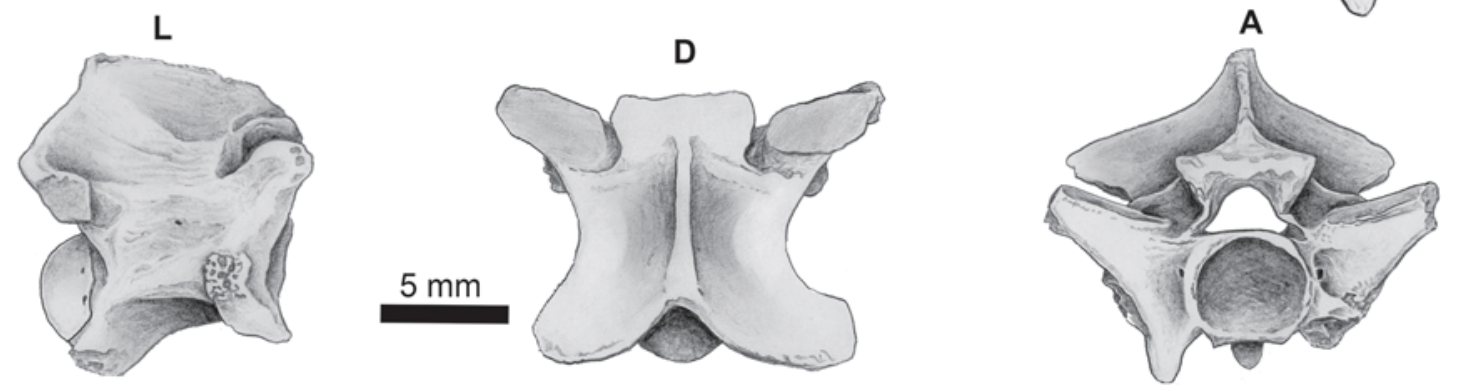
4 Fig. 4 Mid-trunk vertebrae of large European fossil viperids. a Daboia maxima (early Pliocene of Layna, Spain). b Viperidae indet. (late Pliocene of Tourkobounia 1, Greece). c Macrovipera kuchurganica (early Pliocene of Kuchurgan, Ukraine). d Viperidae indet. (early Miocene of Langenau, Germany). e Viperidae indet. (early Miocene of Vieux-Collonges, France). a From Szyndlar 1988; b, c from Szyndlar 1991; d, e from Szyndlar and Rage 1999; Images used with permission. $A$ anterior view, $D$ dorsal view, $L$ lateral view, $P$ posterior view, $V$ ventral view

Species of "Oriental vipers" are differentiated from the much smaller European vipers by having much larger and relatively shorter vertebral centra, relatively higher neural spines and longer hypapophyses (Szyndlar 1987a, 1988). "Oriental vipers" from Europe, achieved a fairly large size already by the early to middle Miocene, as it is documented by large vertebrae from the localities of Langenau, Steinheim and Sandelzhausen (Germany) and La Grive and Artenay (France) (Szyndlar and Rage 1999) (Fig. 4d). They quickly became rather diverse and widespread throughout Europe: apart from the Greek records from Maramena and Tourkobounia 1 that were mentioned above, large "Oriental vipers" are also known from several other localities from the continent. It is worth noting that they are known from both edges of the Mediterranean Europe: in the East, an exceptionally large specimen of Macrovipera lebetina from the Neolithic site of Aetokremnos, Cyprus (10th millennium BC) (Bailon 1999), whereas in the West, Bailon et al. (2010) described a fragmentary vertebra belonging to a large "Oriental viper" from Calo del Rafelino of Mallorca. With a centrum length of the trunk vertebra equal to $12.70 \mathrm{~mm}$, the Mallorca viperid is even larger than Daboia maxima, whereas the authors suggested a body length of "close or greater than $200 \mathrm{~cm}$ " (Bailon et al. 2010:151). More recently, an even larger viperid was described from the Pliocene of Na Burguesa-1, Mallorca (Torres et al. 2014). Large snakes of the 'Oriental vipers complex' have also been recorded from the Pliocene of Iles Medas, Spain and Vallée de la Canterrane, France (Bailon 1991).

Smaller, but still of considerable size, "Oriental viper" taxa have also been reported from the central part of eastern Europe: Macrovipera sarmatica and M. kuchurganica. The former species, from the late Miocene (MN 9) of Calfa (Kalfa), Moldova is believed to have attained a fairly large size, estimated on the basis of a centrum length of $9.10 \mathrm{~mm}$ (Zerova et al. 1987; Szyndlar 1991), whereas the latter originates from the early Pliocene of Kuchurgan, Ukraine, and bears strong resemblance with the extant Macrovipera lebetina (Zerova et al. 1987; Szyndlar 1991) (Fig. 4c). As was noted by Szyndlar and Rage (2002), Macrovipera sarmatica has also a bizarre taxonomic history: it was published as a new species by its name giving authors, Chkhikvadze and Lungu, in two different papers
(Zerova et al. 1987; Lungu et al. 1989)! Zerova et al. (1987) also described another large, but unnamed viperid from Rustavi, Georgia.

Still undescribed specimens of "Oriental vipers" have been repeatedly mentioned in the literature, indicating the broad distribution of these snakes in Europe during the Neogene (Delfino 2002; Szyndlar and Rage 2002). Szyndlar (1988) briefly mentioned an undescribed viperid of "enormous size" from the Pliocene of Vilafant, Spain. The fact, however, that these specimens are still undescribed, hinders establishment of their affinities within Viperidae. Nevertheless, large to giant vipers were widespread in Europe during the Neogene, with their range being contracted only to the Mediterranean edges of the continent by the Pliocene. Large vipers probably did not survive the Plio-Pleistocene in western Europe as there are no post Pliocene fossils from that area, whereas they still survive in the eastern edge of the continent, having extant representatives in the Greek islands (Macrovipera schweizeri) and Cyprus (Macrovipera lebetina).

\section{Conclusions}

A precloacal vertebra, found in the early Pliocene of Megalo Emvolon, northern Greece, is referred to the enigmatic viperid species L. crotaloides, previously described from the same locality. As the type and previously only known material of this taxon is considered lost, the new vertebra described herein represents the sole available specimen for $L$. crotaloides. The vertebra is highly fragmentary, but nevertheless bears a unique combination of characters (very large vertebral size, with CL equal or larger than $15 \mathrm{~mm}$; centrum proportionally short and broad in ventral view; cotyle much wider than the neural canal; condyle stout and proportionally large, elliptical in shape and being slightly wider than tall; diapophyses probably more developed than the parapophyses; and well developed parapophyseal processes) that enables us to diagnose $L$. crotaloides. The exact affinities of this species within the Viperidae still cannot be concluded with certainty, but its specific validity is justified. The presence of a giant viperid snake in the Pliocene of Greece is confirmed. The new specimen further adds to the diversity and distribution of fossil vipers from the country and the giant vipers of Europe in general.

Acknowledgments Wilma Wessels and Hans de Bruijn (University of Utrecht) are thanked for the long term loan of the material and for having provided information about its collection. Marco Pavia (University of Torino) took the photo of the new Laophis crotaloides vertebra. Sandra Chapman (Natural History Museum, London) kindly checked the catalogues and the collection of the Natural History 
Museum. Walter Joyce (University of Fribourg), Dimitris Kostopoulos (Aristotle University of Thessaloniki), George Koufos (Aristotle University of Thessaloniki), Petros Lymberakis (Natural History Museum of Crete, Herakleion) and John Murphy (The Field Museum, Chicago) gave significant help with the literature and provided valuable comments. We also thank our editor Daniel Marty, and our reviewers Jean-Claude Rage, Jim Mead and one anonymous reviewer for providing important comments that enhanced the quality of this paper. Project supported by Fondi di Ateneo (ex 60 \%) 20132014 dell'Università di Torino and Generalitat de Catalunya (2014 SGR 416 GRC).

\section{References}

Arambourg, C., \& Piveteau, J. (1929). Les vertebres du Pontien de Salonique. Annales de Paléontologie, 18, 59-138.

Bachmayer, F., Młynarski, M., \& Symeonidis, N. (1980). Fossile Schildkroten aus dem Pliozan von Megalo Emvolo (Karaburun) bei Saloniki (Griechenland) A. Eine fossile Maurische Landschildkrote (Testudo cf. graeca Linne) B. Fossile reste von Riesenschilkroten. Annales Géologiques des Pays Helléniques, $31,267-276$

Bailon, S. (1991). Amphibiens et Reptiles du Pliocène et du Quaternaire de France et d'Espagne: mise en place et évolution des faunes. PhD dissertation, Université de Paris VII, Paris, France, $499+89 \mathrm{pp}$

Bailon, S. (1999). Toad and snake. In A. H. Simmons (Ed.), Faunal extinction in an island society (pp. 182-186). New York: Kluwer Academic/Plenum Publishers.

Bailon, S., Bover, P., Quintana, J., \& Alcover, J. A. (2010). First fossil record of Vipera Laurenti 1768 "Oriental vipers complex" (Serpentes: Viperidae) from the Early Pliocene of the western Mediterranean islands. Comptes Rendus Palevol, 9, 147-154.

Boev, Z., \& Koufos, G. (2000). Presence of Pavo bravardi (Gervais, 1849) (Aves, Phasianidae) in the Ruscinian locality of Megalo Emvolon, Macedonia, Greece. Geologica Balcanica, 30, 69-74.

Böhme, M. (2003). The Miocene climatic optimum: evidence from ectothermic vertebrates of Central Europe. Palaeogeography, Palaeoclimatology, Palaeoecology, 195, 389-401.

Bonaparte, L. (1835). Iconographia della Fauna Italica per le quattro classi degli animali vertebrati. Tome 2 (264 pp.). Rome: Salviucci.

Čerňanský, A., Rage, J.-C., \& Klembara, J. (2015). The Early Miocene squamates of Amöneburg (Germany): the first stages of modern squamates in Europe. Journal of Systematic Palaeontology, 13, 97-128.

de Bruijn, H. (1984). Remains of the mole-rat Microspalax odessanus Topachevski, from Karaburun (Greece, Macedonia) and the family Spalacidae. Proceedings Koninklijke Nederlandse Akademie van Wetenschappen $B, 87,417-424$

Delfino, M. (2002). Erpetofaune italiane del Neogene e del Quaternario. PhD dissertation, University of Modena and Reggio Emilia, Modena and Reggio Emilia, Italy, $382 \mathrm{pp}$.

Delfino, M., Kotsakis, T., Arca, M., Tuveri, C., Pitruzella, G., \& Rook, L. (2008). Agamid lizards from the Plio-Pleistocene of Sardinia (Italy) and an overview of the European fossil record of the family. Geodiversitas, 30, 641-656.

Delfino, M., Segid, A., Yosief, D., Shoshani, J., Rook, L., \& Libsekal, Y. (2004). Fossil reptiles from the Pleistocene Homo-bearing locality of Buia (Eritrea, Northern Danakil Depression). In E. Abbate, B. Woldehaimanot, Y. Libsekal, T.M. Tecle \& L. Rook (Eds.), A step towards human origins. The Buia Homo onemillion-years ago in the Eritrean Danakil Depression (East
Africa) (pp. 51-60). Rivista Italiana di Paleontologia e Stratigrafia, 110 (supplement) (144 pp). Milano: Università di Milano.

Eronen, J., \& Rook, L. (2004). The Mio-Pliocene European primate fossil record: dynamics and habitat tracking. Journal of Human Evolution, 47, 323-341.

Georgalis, G. L., \& Kear, B. P. (2013). The fossil turtles of Greece: an overview of taxonomy and distribution. Geobios, 46, 299-311.

Georgalis, G. L., Velitzelos, E., Velitzelos, D., \& Kear, B. P. (2013). Nostimochelone lampra gen. et sp. nov., an enigmatic new podocnemidoidean turtle from the lower Miocene of northern Greece. In D. Brinkman, P. Holroyd, \& J. Gardner (Eds.), Morphology and evolution of turtles: papers in honor of Eugene S. Gaffney. Volume 3. Pleurodires (pp. 277-287). Dordrecht: Springer.

Georgalis, G. L., Villa, A., \& Delfino, M. (2016). First description of a fossil chamaeleonid from Greece and its relevance for the European biogeographic history of the group. The Science of Nature, 103, 12. doi:10.1007/s00114-016-1336-5

Golay, P., Smith, H. M., Broadley, D. G., McCarthy, C., Rage, J.-C., Schätti, B., \& Toriba, M. (1993). Endoglyphs and other major venomous snakes of the world. A checklist (478 pp.). Geneva: Azemiops Herpetological Data Center.

Gray, J. E. (1849). Catalogue of the specimens of snakes in the collection of the British Museum (125 pp.). London: Edward Newman.

Herrmann, H.-W., Joger, U., \& Nilson, G. (1992). Phylogeny and systematics of Viperinae snakes. III: resurrection of the genus Macrovipera (Reuss, 1927) as suggested by biochemical evidence. Amphibia-Reptilia, 13, 375-392.

Hoffstetter, R. (1938). Ophidiens fossiles. Bulletin de la Société Linnéenne de Lyon, 7, 230-234.

Hoffstetter, R. (1955). Squamates de type moderne. In J. Piveteau (Ed.), Traité de Paléontologie, Tome V (Amphibiens, Reptiles, Oiseaux) (pp. 606-662). Paris: Masson et Cie.

Holman, J. A. (2000). Fossil snakes of North America. Origin, evolution, distribution, paleoecology (376 pp.). Bloomington and Indianapolis: Indiana University Press.

ICZN (International Commission on Zoological Nomenclature). (1999). International code of zoological nomenclature (4th ed.). London: International Trust for Zoological Nomenclature.

Ivanov, M. (1999). The first European pit viper from the Miocene of Ukraine. Acta Palaeontologica Polonica, 44, 327-334.

Kinkelin, F. (1892). Ein fossiler Giftzahn. Zoologischer Anzeiger, 15, 93-94.

Kormos, T. (1911). A Polgárdi pliocén csontlelet. Földtani Közlöny, $41,48-64$.

Koufos, G. D. (1997). The canids Eucyon and Nyctereutes from the Ruscinian of Macedonia, Greece. Palaeontologia i Evolucio, 30$31,39-48$.

Koufos, G. D. (2006). The Neogene mammal localities of Greece: faunas, chronology, and biostratigraphy. Annales Géologiques des Pays Helléniques, 4, 183-214.

Koufos, G. D., \& Koliadimou, K. (1993). Two lagomorphs from the Pliocene of Macedonia (Greece). Bulletin of the Geological Society of Greece, 28, 117-129.

Koufos, G., Syrides, G., \& Koliadimou, K. (1991). A Pliocene primate from Macedonia. Journal of Human Evolution, 21, 283-294.

Kuhn, O. (1939). Squamata: Lacertilia et Ophidia. In W. Quenstedt (Ed.), Fossilium Catalogus, I: Animalia, pars 86 (122 pp.). Neubrandenburg: Verlag Gustav Feller.

Kuhn, O. (1963). Serpentes (Supplementum I). In F. Westphal (Ed.), Fossilium Catalogus, I: Animalia, pars 103 (45 pp.). Gravenhage: Uitgeverij Dr. W. Junk.

Laurenti, J. N. (1768). Specimen medicum, exhibens synopsin reptilium emendatam cum experimentis circa venena et antidota 
reptilium austracorum, quod authoritate et consensu (217 pp.). Vienna: Joan. Thomae.

Lenk, P., Kalyabina, S., Wink, M., \& Joger, U. (2001). Evolutionary relationships among the true vipers (Viperinae) inferred from mitochondrial DNA sequences. Molecular Phylogenetics and Evolution, 19, 94-104.

Linnaeus, C. (1758). Systema Naturae per regna tria naturae, secundum classes, ordines, genera, species, cum characteribus, differentiis, synonymis, locis (824 pp.). Stockholm: Laurentii Salvii.

Lungu, A. N., Zerova, G. A., \& Chkhikvadze, V. M. (1989). Large lizards and venomous snakes from the middle Sarmatian of Moldavia and significance of the fossil herpetofauna for paleoclimatology. In Fauna i Flora Mezozoya $i$ Kaynozoya Yuzhnykh Okrain Russkoy Platformy (pp. 59-69). Kishinev: Izdatelstvo Shtiintsa (in Russian).

Maempel, G. Z. (1986). T.A.B. Spratt (1811-88) and his contribution to maltese geology. Melita Historica, 9, 271-308.

Mallow, D., Ludwig, D., \& Nilson, G. (2003). True vipers. Natural history and toxinology of old world vipers (359 pp.). Malabar: Krieger Publishing Company.

Marsh, O. C. (1871). Description of some new fossil serpents, from the Tertiary deposits of Wyoming. The American Journal of Science and Arts, series, 3(1), 322-329.

Młynarski, M., Szyndlar, Z., Estes, R., \& Sanchiz, B. (1982). Lower vertebrate fauna from the Miocene of Opole (Poland). Estudios Geológicos, 38, 103-119.

Nilson, G., \& Andrén, C. (1986). The mountain vipers of the Middle East - the Vipera xanthina complex (Reptilia, Viperidae). Bonner Zoologische Monographien, 20, 1-90.

Oppel, M. (1811). Die Ordnungen, Familien, und Gattungen der Reptilien als Prodrom einer Naturgeschichte derselben (p. 86). München: Joseph Lindauer.

Owen, R. (1857). On the fossil vertebrae of a Serpent (Laophis crotaloïdes, Ow.) discovered by Capt. Spratt, R.N., in a tertiary formation at Salonica. Quarterly Journal of the Geological Society of London, 13, 196-199.

Piveteau, J. (1927). Etudes sur quelques amphibiens et reptiles fossiles. 1ère partie. Annales de Paléontologie, 16, 61-97.

Rage, J.-C. (1984). Serpentes. In P. Wellnhofer (Ed.), Encyclopedia of paleoherpetology, part 11 (80 pp.). Stuttgart, New York: G. Fischer.

Rage, J.-C., \& Bailon, S. (2011). Chapter 16, amphibia and squamata. In T. Harrison (Ed.), Paleontology and geology of laetoli: human evolution in context. Volume 2: fossil hominins and the associated fauna, vertebrate paleobiology and paleontology (pp. 467-478). New York: Springer.

Richter, A. (1995). The vertebrate locality Maramena (Macedonia, Greece) at the Turolian-Ruscinian Boundary (Neogene). 3. Lacertilia (Squamata, Reptilia). Münchner Geowissenchaften Abhandlungen, 28, 35-38.

Rochebrune, A. T. de (1880). Revision des ophidiens fossiles du Museum d'Histoire Naturelle. Nouvelles Archives du Muséum d'Histoire Naturelle, $2^{\text {ème }}$ Série, 3, 271-296.

Romer, A. S. (1956). Osteology of the reptiles (772 pp.). Chicago: University of Chicago Press.

Römer, F. (1870). Über Python euboicus, eine fossile Riesenschlange aus tertiärem Kalkschiefer von Kumi auf der Insel Euboea. Zeitschrift der Deutschen Geologischen Gesellschaft, 22, 582590.

Schneider, B. (1975). Ein mittelpleistozane Herpetofauna von der Insel Chios, Agais. Senckenbergiana biologica, 56, 191-198.

Spawls, S., Howell, K., Drewes, R., \& Ashe, J. (2002). A field guide to reptiles of East Africa (546 pp.). London and San Diego: Academic Press.
Spratt, T. A. B. (1842). Notices connected with the geology of the island of Rhodes. Proceedings of the Geological Society of London, 3, 773-775.

Spratt, T. A. B. (1847). Remarks on the geology of the island of Samos. Quarterly Journal of the Geological Society of London, 3, 65-67.

Spratt, T. A. B. (1857). On the freshwater deposits of Euboea, the coast of Greece and Salonika. Quarterly Journal of the Geological Society of London, 13, 177-184.

Steffens, P., Bruijn, H. de, Meulenkamp, J. E., \& Benda, L. (1979). Field guide to the Neogene of northern Greece (Thessaloniki area and Strimon basin). Publications of the Department of Geology and Paleontology of the University of Athens series A, 35, 1-14.

Syrides, G. E. (1990). Lithostratigraphical, biostratigraphical and palaeogeographical study of the Neogene/Quaternary sedimentary formations of Chalkidiki peninsula. $P h D$ dissertation, Aristotle University of Thessaloniki, Thessaloniki, Greece, 243 pp. [in Greek]

Szyndlar, Z. (1984). Fossil snakes from Poland. Acta Zoologica Cracoviensia, 28, 1-156.

Szyndlar, Z. (1987a). Neogene "Oriental vipers" of Europe. In J. J. van Gelder, H. Strichbosch, \& P. J. M. Bergers (Eds.), Proceedings of the 4th ordinary general meeting of the societas europaea herpetologica (pp. 378-390). Nijmegen: Catholic University.

Szyndlar, Z. (1987b). Snakes from the lower miocene locality of Dolnice (Czechoslovakia). Journal of Vertebrate Paleontology, 7, $55-71$.

Szyndlar, Z. (1988). Two new extinct species of the genera Malpolon and Vipera (Reptilia, Serpentes) from the Pliocene of Layna Spain. Acta Zoologica Cracoviensia, 31, 687-706.

Szyndlar, Z. (1991). A review of neogene and quaternary snakes of Central and Eastern Europe. Part II: Natricinae, Elapidae, Viperidae. Estudios Geologicos, 47, 237-266.

Szyndlar, Z. (1992). "Coluber" kargii von Meyer, 1845 (Serpentes: Viperidae), from the Miocene of Öhningen (Germany). Neues Jahrbuch für Geologie und Paläontologie Monatshefte, 1992 (11), 692-700.

Szyndlar, Z. (1995). The vertebrate locality Maramena (Macedonia, Greece) at the Turolian-Ruscinian Boundary (Neogene). 4. Serpentes (Squamata, Reptilia). Münchner Geowissenchaften Abhandlungen, 28, 35-39.

Szyndlar, Z., \& Rage, J.-C. (1999). Oldest fossil vipers (Serpentes: Viperidae) from the old World. Kaupia, 8, 9-20.

Szyndlar, Z., \& Rage, J.-C. (2002). Fossil record of the true vipers. In G. Scuett, M. Hoggren, M. Douglas, \& H. Greene (Eds.), Biology of the vipers (pp. 419-441). Eagle Mountain: Eagle Mountain Publishing.

Torres E., Bailon, S., Bover, P., \& Alcover, J. A. (2014). Sobre la presencia de un vipérido de gran talla perteneciente al complejo de víboras Orientales en el yacimiento de $\mathrm{Na}$ Burguesa-1 (Mioceno superior/Plioceno inferior, Mallorca). In R. RoyoTorres, F. J. Verdú \& L. Alcalá (Eds.) XXX Jornadas de Paleontología de la Sociedad Española de Paleontologia Fundamental, 24, 237-240. Teruel: Fundación Conjunto Paleontológico de Teruel-Dinópolis.

Valakos, E. D., Pafilis, P., Sotiropoulos, K., Lymberakis, P., Maragou, P., \& Foufopoulos, J. (2008). Amphibians and reptiles of Greece (463 pp.). Frankfurt: Chimaira.

van Vugt, N. (2000). Orbital forcing in late Neogene lacustrine basins from the Mediterranean. A magnetostratigraphic and cyclostratigraphic study. Geologica Ultraiectina, 189, 167.

Wallach, V., Williams, K. L., \& Boundy, J. (2014). Snakes of the world: a catalogue of living and extinct species (1237 pp.). Boca Raton, London and New York: CRC Press. 
Werner, F. (1935). Reptilien der Ägäischen Inseln. Sitzungsberichte der Kaiserlichen Akademie der Wissenschaften Wien, 144, 81117.

Zerova, G. A., Lungu, A. N., \& Chkhikvadze, V. M. (1987). Large fossil vipers from northern Black Seaside and Transcaucasus. Trudy Zoologicheskogo Instituta, 158, 89-99.
Zittel, K. A. von (1887-1890). Handbuch der Paläontologie. Abteilung 1. Paläozoologie Band III. Vertebrata (Pisces, Amphibia, Reptilia, Aves) (900 pp.). Munich, Leipzig: Oldenbourg. 